This report was prepared as an account of work sponsored by an agency of the United States Government. Neither the United States Government nor any agency thereof, nor any of their employees, makes any warranty, express or implied, or assumes any legal liability or responsibility for the accuracy, completeness, or usefulness of any information, apparatus, product, or process disclosed, or represents that its use would not infringe privately owned rights. Reference herein to any specific commercial product, process, or service by trade name, trademark, manufacturer, or otherwise does not necessarily constitute or imply its endorsement, recommendation, or favoring by the United States Government or any agency thereof. The views and opinions of authors expressed herein do not necessarily state or reflect those of the United States Government or any agency thereof.

\title{
RESOLUTION OF THYLAKOID POLYPHENOL OXMASE AND A PROTEIN KINASE
}

Helen L. Race, James W. Davenport ${ }^{1}$ and Geoffrey Hind Biology Department, Brookhaven National Laboratory, Upton, New York 11973, USA; 'Present address: Biology Department, University of Memphis, Memphis, Tennessee 38152, USA.

\section{Introduction}

The predominant protein kinase activity in octylglucoside (OG) extracts of spinach thylakoids has been attributed to a $64-\mathrm{kDa}$ protein, tp64. Recent work (1) calls into question the relation between tp64 and protein kinase activity, which were fractionated apart using fluid phase IEF and hydroxylapatite chromatography. Hind et al. (2) sequenced tp64 from the cDNA and showed it to be a polyphenol oxidase (PPO) homolog. Its transit peptide indicates a location for the mature protein within the thylakoid lumen, where there is presumably no ATP and where it is remote from the presumed kinase substrates: the stromally exposed regions of integral PS-II membrane proteins. Here we suggest that the kinase is a $64-\mathrm{kD}$ a protein distinct from tp64.

\section{Procedures}

An OG-cholate extract of spinach thylakoids was prepared as described in (3). Isolation of OG extract, assay of histone phosphorylation, and SDS-PAGE procedures were as described (1). OG-cholate extract (4 $\mu \mathrm{g}$ protein) previously radiolabeled as in (1) was digested at $20^{\circ} \mathrm{C}$ with TPCK-trypsin (Worthington) and the reactions were terminated by adding a 20 -fold excess of soybean trypsin inhibitor. OG extract was affinity purified on $\gamma$-phosphate-linked ATP-Sepharose (Upstate Biotechnology) by the procedure in (4).

\section{Results and Discussion}

Discrimination between tp64 and protein kinase by tryptic digestion Figure 1 shows the effect of controlled trypsinolysis on a crude OG-cholate ("P300") extract of thylakoids. Work elsewhere showed that trypsin activates PPO in spinach and

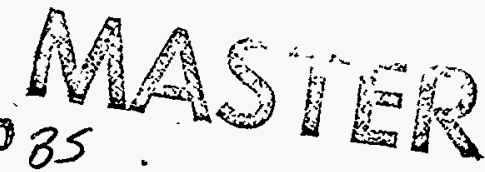


Vicia faba as the molecule is cleaved at a sensitive site to yield peptides of ca. 42 and $18 \mathrm{kDa}(5,6)$. Tryptic digestion is shown in Fig.1A for spinach PPO (tp64) in the OG-cholate extract, previously phosphorylated by preincubation with $\left[\gamma^{32} \mathrm{P}\right]$ ATP. The stained gel shows progressive loss of a band at $64 \mathrm{kDa}$ accompanied by the appearance of bands at 43 and $22-23 \mathrm{kDa}$. The identity of the $64 \mathrm{kDa}$ protein as tp64 PPO was confirmed by Western blotting (not shown). The autoradiograph, Fig. 1B, shows that radiolabel in the tp64 PPO band is lost in proportion to the stain density, and appears in the $22-23 \mathrm{kDa}$ but not the $43 \mathrm{kDa}$ fragment. N-terminal sequencing and Western blotting both confirm that this larger peptide has an intact tp64 $\mathrm{N}$-terminus (predicted: APILPDV-; determined sequence: APILPXV-).

A

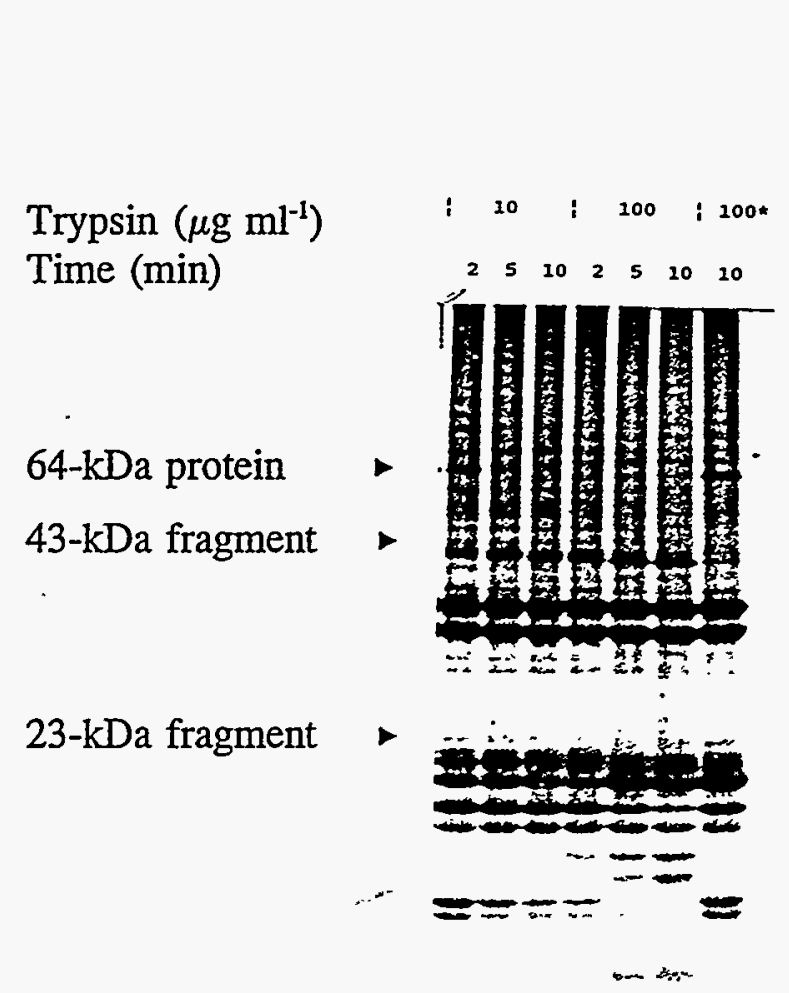

B

Kinase activity $/ \%$ of control

$\begin{array}{lll}83 & 58 \quad 77\end{array}$

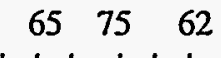

$\begin{array}{llllll}1 & 1 & 1 & 1 & 1 & 1\end{array}$

$10: 100: 100 *$

$\begin{array}{llllllll}2 & 5 & 10 & 2 & 5 & 10 & 10 & \mathrm{WH}\end{array}$
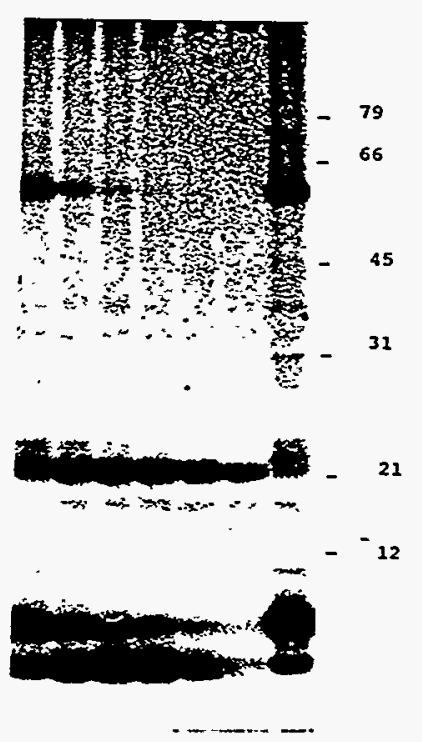

Figure 1. Progressive trypsinolysis of OG-cholate extract. A: silver-stained gel. B: autoradiograph. * Control with trypsin inhibitor added before trypsin.

Thus the phosphorylation site is in a C-terminal $22-23 \mathrm{kDa}$ peptide. The $22-23 \mathrm{kDa}$ phosphopeptide observed in the control lane of Fig. 1, and in published autoradiographs of phosphorylated fractions from OG extracts of thylakoids, is almost certainly derived from tp64 by partial proteolysis during fractionation, since Western blotting with a tp64 N-terminus antibody in such cases reveals both tp64 and its 43-kDa fragment. The Western blot in Fig. 2 exemplifies this situation. 
Table 1 suggests sequences for the C-terminal peptide.

Table 1. C-terminal region of tp64 (spinach thylakoid PPO) corresponding to putative tryptic peptides of 21.7-23.5 kDa. Data from GenBank accession number U19270.

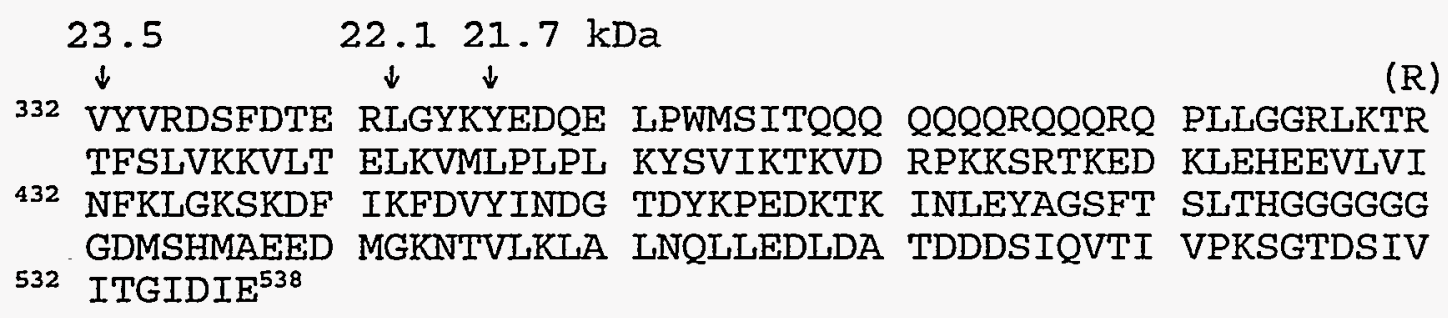

Figure 1 also gives rates of histone phosphorylation, assayed after adding soybean trypsin inhibitor. Proteolytic digestion to a point where tp64 was no longer seen as a stained or radiolabeled band, inhibited the histone phosphorylation rate by only $38 \%$.

\section{Affinity purification of a 64-kDa protein on ATP-Sepharose}

Cross-linking of ATP to Sepharose through its $\gamma$-phosphate residue avoids modifying the adenine and ribose moieties, which are critical to recognition by protein kinase active sites. Figure 2 shows the polypeptide profiles of samples obtained by passing OG extract through a $0.5 \mathrm{ml}$ column of this affinity matrix. Analysis by blotting with antibody to the tp64 $\mathrm{N}$-terminus conclusively demonstrates that tp64 is present in the material loaded and in the flow-through. However, there is no immunoreaction between tp64 antibody and the $\approx 64 \mathrm{kDa}$ protein eluted with ATP. The $64-\mathrm{kDa}$ material in the ATP fractions is evidently considerably concentrated with respect to the OG extract, and it is the most abundant protein in this fraction as judged by silver stain density. We have not been successful in recovering histone kinase activity in any fraction from this column, including the flow-through. $\mathrm{NaCl}$ washes $(1 \mathrm{M}$ ) containing $0.05 \%$ Triton $\mathrm{X}-100$ (not shown) do not release additional protein. This result is reminiscent of our earlier inability (3) to recover active protein kinase from Cibacron Blue-agarose affinity chromatography. Possibly there is sufficient affinity ligand (adenosine-5'- $(\gamma-4$-aminophenyl)triphosphate) leaching from the matrix to inactivate any kinase present. Minor stained bands occur in the ATP eluate, at masses around 37 and $110 \mathrm{kDa}$. The same bands also accompanied the major $\approx 64-\mathrm{kD}$ a phosphoprotein in a kinase-enriched fraction from fluid-phase isoelectric purification of an OG extract (shown in lane R, reproduced from (1)) and were identified (1) as FNR and glycine decarboxylase P-subunit. The presence of these satellites is in both cases consistent with their serving as phosphorylation substrates, which could tend to copurify with the kinase. Logically, the most abundant and heavily labeled protein would be the protein kinase iself, with a mass of $\approx 64 \mathrm{kDa}$. 